\title{
PERAN GEN STRUKTURAL, GEN NON-STRUKTURAL, DAN UNTRANSLATED REGION DALAM PERAKITAN VIRUS DENGUE
}

\author{
Meiranty C. Pangerapan \\ Beivy J. Kolondam
}

\author{
Jurusan Biologi Fakultas MIPA Universitas Sam Ratulangi Manado \\ E-mail: pangerapanmeiranty@gmail.com; beivy.kolondam@unsrat.ac.id
}

\begin{abstract}
Dengue virus is a single-stranded RNA virus that belongs to Flaviviridae family. This virus causes dengue fever which is transmitted by Aedes aegypti dan Aedes albopictus. There are four serotypes of dengue virus; all of them can cause dengue fever. Understanding the genomics of dengue virus is important for research and diagnostics. The genome of dengue virus is 11 kilo-base long. It consists of 5'-untranslated region (5'-UTR), three structural genes (coding capsid protein, pre-membrane/membrane, and envelope), seven non-structural genes (coding NS1, NS2A, NS2B, NS3, NS4A, NS4B, and NS5 proteins) and 3'-UTR. Nonstructural genes are encoding proteins of viral RNA replication, interferon response, viral assembly and secretion, endoplasmic reticulum membrane invagination induction, immunemediator induction, and RNA 5'-caping.
\end{abstract}

Keywords: dengue virus, genome, structural genes, non-structural genes, untranslated region.

\begin{abstract}
Abstrak: Virus dengue merupakan virus RNA beruntai tunggal yang termasuk dalam famili Flaviviridae. Virus ini adalah penyebab penyakit demam berdarah dengue yang ditransmisikan melalui nyamuk Aedes aegypti dan Aedes albopictus. Ada empat serotipe virus dengue yang telah dikenal secara luas yang ada semuanya dapat menimbulkan penyakit demam berdarah. Pemahaman tentang genomik virus dengue sangat penting untuk pengembangan penelitian dan juga untuk keperluan diagnostik. Genom virus dengue memiliki panjang 11 kilo basa. Genomnya tersusun atas 5'-untranslated region (5'-UTR), tiga gen struktural (mengodekan protein kapsid, premembran/membran dan amplop), tujuh gen non-struktural (mengodekan protein NS1, NS2A, NS2B, NS3, NS4A, NS4B dan NS5) dan 3'-UTR. Gen-gen nonstruktural mengodekan protein untuk replikasi RNA virus, respon interferon, perakitan, sekresi partikel virus, menginduksi invaginasi membran retikulum endoplasma, induksi imunomediator dan penambahan tudung pada ujung 5' RNA.
\end{abstract}

Kata kunci: virus dengue, genom, gen struktural, gen non-struktural, untranslated region

Virus Dengue (DENV) adalah penyebab penyakit demam berdarah dengue yang ditransmisikan melalui nyamuk. Terdapat 4 serotipe DENV yang telah dikenal secara luas yang ada semuanya dapat menimbulkan penyakit demam berdarah yang disebut dengue fever (DF), dengue hemorraghic fever (DHF), dan dengue shock syndrome (DSS). ${ }^{1}$ Salah satu aspek penelitian DENV dalam bidang molekuler yang masih terus diminati ialah genomik virus ini yang berkaitan erat dengan diversitas berupa serotipe virus dengue. Pembahasan tentang genomik DENV sangat penting untuk analisis virus tersebut di Indonesia. Pengembangan penelitian DENV di bidang medis akan lebih mudah dilakukan bila tersedia informasi mengenai genomik untuk keperluan diagnostik dan penentuan serotipe. 
Dengue merupakan virus RNA beruntai tunggal yang termasuk dalam genus Flavivirus dengan nama famili Flaviviridae. ${ }^{2-4}$ Transmisi DENV antar manusia diperantarai oleh vektor nyamuk spesies Aedes aegypti dan Aedes albopictus. Gejala infeksi mulai terlihat dalam rentang 4-7 hari setelah gigitan nyamuk dan bertahan selama 3-10 hari. Agar transmisi dari manusia ke nyamuk dapat terjadi, nyamuk harus menghisap darah orang yang terinfeksi DENV pada hari ke-5 karena pada saat itu virus terdapat dalam jumlah yang paling melimpah. Setelah berada dalam tubuh nyamuk, dibutuhkan waktu 8-12 hari sebelum virus dapat ditransmisikan ke manusia. Nyamuk yang telah terinfeksi DENV akan tetap membawa DENV dalam tubuhnya seumur hidupnya. Pada kasus yang sangat langka, DENV dapat ditransmisikan melalui transplantasi organ, transfusi darah dari donor yang terinfeksi, atau dari ibu ke fetus dalam kandungan. ${ }^{1}$

\section{VIRUS DENGUE}

\section{Serotipe virus dengue}

Hingga saat ini, terdapat 4 serotipe DENV yang telah dikenal secara luas, yaitu DENV-1, DENV-2, DENV-3, dan DENV4. Pembagian DENV ke dalam 4 serotipe didasarkan pada perbedaan antigenitas yang dimiliki. Perbedaan serotipe DENV disebabkan oleh perbedaan susunan nukleotida yang mengodekan protein kapsid dan membran. ${ }^{5}$ Perbedaan serotipe DENV ditentukan dengan melakukan analisis sekuens nukleotida pada daerah pertemuan gen C-prM. Perbedaan serotipe ini membatasi kemampuan tubuh yang terinfeksi dalam memberikan perlindungan silang terhadap infeksi serotipe DENV yang lain. ${ }^{3,6}$

Parahnya penyakit demam berdarah yang disebabkan oleh DENV berkaitan dengan infeksi sekunder oleh virus yang mempunyai serotipe yang berbeda dengan virus yang menginfeksi pertama kali. ${ }^{7}$ Infeksi oleh satu serotipe menginduksi imunitas jangka panjang terhadap serotipe tersebut, namun tubuh yang telah terinfeksi tidak dapat memberikan imunitas silang terhadap serotipe lain. Bila orang tersebut selanjutnya terinfeksi oleh serotipe lain, virus akan berikatan dengan cross reactive nonneutralising antibody yang berasal dari infeksi sebelumnya. Ikatan ini memudahkan fagositosis oleh fagosit mononuklear dan mempercepat replikasi virus dalam fagosit tersebut sehingga jumlah virus dalam darah meningkat drastis. Hal ini meningkatkan permeabilitas mikrovaskuler dan pelepasan sitokin yang menyebabkan DHS, dan dalam situasi terburuk dapat terjadi DSS. ${ }^{8}$

Selain infeksi sekunder, evolusi dan infeksi multiserotipe juga merupakan penyebab epidemi dengue. ${ }^{6}$ Orang yang tinggal di daerah endemik DENV mungkin saja terinfeksi oleh keempat serotipe DENV secara berulang semasa hidupnya. ${ }^{9}$

\section{Genom virus dengue}

Genom virus dengue merupakan molekul RNA beruntai tunggal positif yang kurang lebih mengandung 11.000 basa. Genom DENV (Gambar 1) tersusun atas 5'-untranslated region (5'-UTR), 3 gen struktural [mengodekan protein kapsid (C), premembran/membran (prM/M) dan amplop (E)], 7 gen nonstruktural (NS) (mengodekan protein NS1, NS2A, NS2B, NS3, NS4A, NS4B dan NS5) dan 3'-UTR. ${ }^{4}$ Ujung 5' RNA DENV ditutupi tudung tipe I (m7GpppAmpN2), tetapi tidak ditemukan ekor poli(A) pada ujung 3'.10 Semua gen virus terdapat pada daerah yang disebut open reading frame (ORF) yang akan menghasilkan 1 untai polipeptida yang tidak terputus. Polipeptida ini tersusun atas 3.400 asam amino yang kemudian akan mengalami pemrosesan pasca translasi untuk menghasilkan protein-protein fungsional. ${ }^{6}$

Ketujuh gen nonstruktural pada genom DENV masing-masing mengodekan protein nonstruktural yang memiliki fungsi tertentu. NS1 merupakan glikoprotein 46 $\mathrm{kDa}$ dan fungsinya dalam sel inang masih belum diketahui pasti, namun diduga 
glikoprotein ini berperan dalam replikasi RNA virus. ${ }^{11}$ NS1 yang disekresikan ke luar sel dapat terikat pada platelet dan sel endotel yang berakhir dengan disfungsi endotel dan kebocoran vaskuler. ${ }^{12}$

NS2A merupakan protein hidrofobik yang berperan dalam replikasi RNA, respon interferon dan perakitan, serta sekresi partikel virus. ${ }^{13}$ NS2B bersama dengan NS3 berperan dalam proses pasca translasi sebagai protease yang memotong polipeptida untuk menghasilkan protein tunggal yang terpisah-pisah. ${ }^{14}$ Protein NS4A berperan dalam menginduksi invaginasi membran retikulum endoplasma (RE) selama pembentukan kompleks replikasi. $^{10}$ NS4B terutama bertanggung jawab dalam induksi imunomediator seperti IL6, IL-8, IP-10, TNF $\alpha$ dan IFN $\gamma \cdot{ }^{15}$ NS5 merupakan protein terbesar yang dihasilkan oleh DENV ( 105kDa) yang memiliki aktivitas enzimatik dan berperan dalam replikasi dan penambahan tudung pada ujung 5' RNA. ${ }^{16}$

\section{Untranslated Region (UTR)}

Bagian 5'-UTR DENV memiliki panjang 95-101 nukleotida. Pada 5'-UTR terdapat 2 domain RNA yang masingmasing memiliki fungsi berbeda selama sintesis RNA virus. Domain I tersusun atas
70 nukleotida, terlipat membentuk sebuah stem-loop yang besar (SLA, Gambar 4). SLA diduga berperan sebagai promotor untuk NS5 yang harus melekat pada SLA agar sintesis RNA dapat dimulai. ${ }^{17}$

Domain II dari 5'-UTR DENV membentuk stem loop pendek (SLB). Dalam SLB terdapat sekuens yang diperlukan untuk interaksi RNA-RNA dalam kisaran yang panjang dan replikasi genom virus. Di antara domain I dan domain II terdapat sekuens oligo (U) disebut oligo spacer yang berfungsi untuk memisahkan kedua domain pada 5'-UTR. Berbagai penelitian yang dilakukan menggunakan probing kimia dan enzimatik menunjukkan bahwa SLA mempunyai struktur berbentuk $\mathrm{Y}^{17}$

Beberapa hasil penelitian memperlihatkan bahwa pada SLA terdapat 3 daerah berbentuk heliks yang mempunyai tonjolan-tonjolan dan daerah beruntai tunggal yang sangat reaktif. Kereaktifan yang tinggi dari daerah ini mungkin disebabkan oleh adanya side stem loop dan top loop (Gambar 2). Selain SLB, terdapat suatu struktur lain yang ditemukan di dekat kodon AUG. Struktur ini disebut stable hair pin (cHP) yang diperlukan untuk replikasi virus DENV. ${ }^{17}$

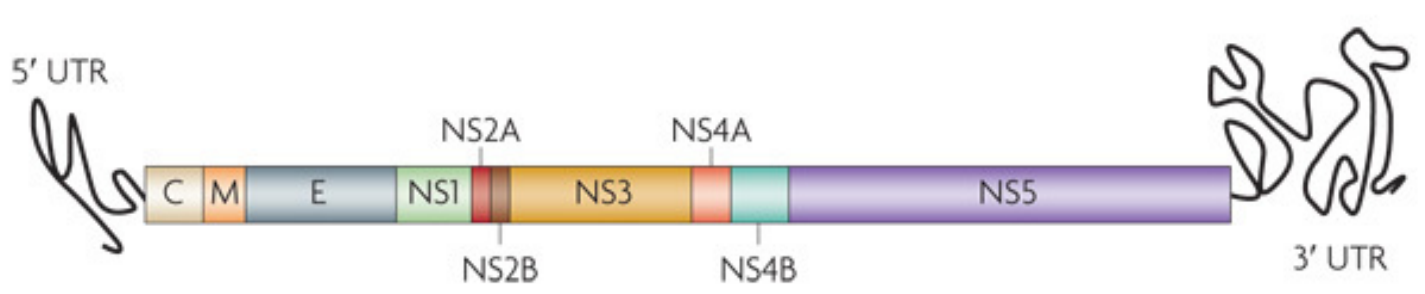

Gambar 1. Genom virus dengue yang mengodekan 3 protein struktural (kapsid C, membran M, dan amplop E) dan 7 protein nonstruktural (NS1, NS2A, NS2B, NS3, NS4A, NS4B dan NS5). Sumber: Guzman MG et al., 2010. ${ }^{7}$

Bagian 3'-UTR yang memiliki panjang sekitar 450 nukleotida dapat dibagi menjadi 3 domain (Gambar 3). Domain I merupakan domain yang paling bervariasi dalam daerah 3'-UTR. Panjang domain I sangat bervariasi antara serotipe DENV yang ada, sehingga disebut juga variable region. ${ }^{10}$ Panjang UTR' 3 pada domain I bisa lebih dari 120 nukleotida atau kurang dari 50 nukleotida.

Pada domain II terdapat sekuens yang disebut CS2 dan RCS2 (ulangan CS2). CS2 
dan RCS2 merupakan sekuens khas yang terdapat pada semua jenis Flavivirus yang menginfeksi nyamuk. Elemen RNA dalam domain I dan II berperan sebagai enhancer dalam berbagai proses molekuler yang dilakukan oleh virus. ${ }^{17}$

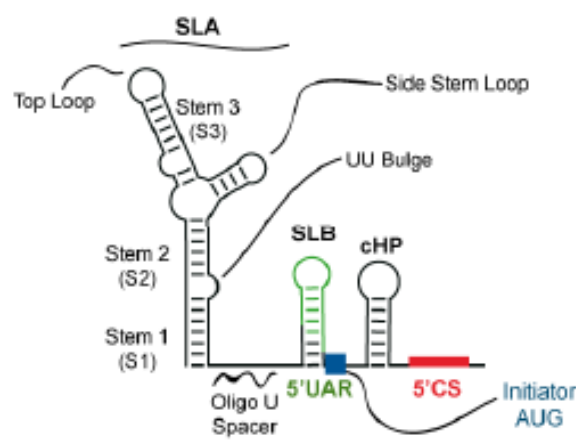

Gambar 2. Bagian 5'-UTR virus dengue. Sumber: Gebhard G et al., 2011. ${ }^{17}$
Pada domain III terdapat elemen CS1 dan struktur terminal stem-loop (3'SL). Pada CS1 terdapat sekuens yang terlibat dalam interaksi RNA-RNA antara kedua ujung genom virus Struktur 3'SL yang terletak di bagian terminal 3' tersusun atas short stem loop (sHP) yang panjangnya 14 nukleotida dan large stem loop yang panjangnya 79 nukleotida. ${ }^{17}$

Jadi, baik daerah 5'-UTR maupun 3'UTR, keduanya memiliki peran yang penting dalam biologi DENV. Dapat dikatakan UTR berperan vital dalam menentukan efisiensi translasi RNA. Selain itu, UTR juga menentukan kemampuan virus dalam menginfeksi inang. Secara tidak langsung, dapat dikatakan bahwa UTR menentukan tingkat keparahan penyakit demam berdarah yang diderita oleh pasien. ${ }^{18}$

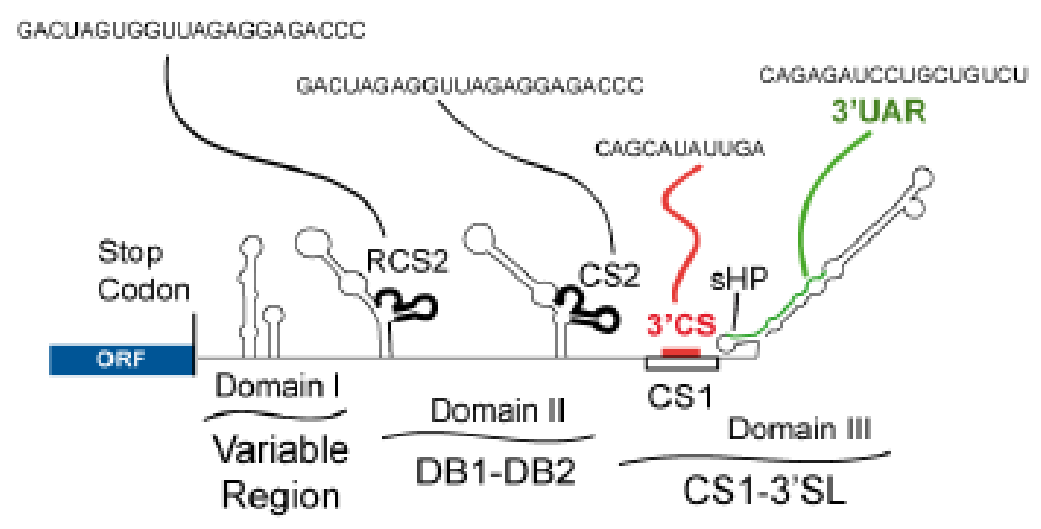

Gambar 3. Bagian 3'-UTR virus dengue. Gebhard G et al., 2011. ${ }^{17}$

\section{REPLIKASI DAN PERAKITAN VIRUS DENGUE}

Genomik RNA DENV bersifat infektif, seperti halnya semua virus untai positif lainnya. Pada kedua ujung ORF genom DENV terdapat dua untranslated region (UTR). Meskipun tidak dapat ditranslasikan, UTR mengandung elemenelemen struktural dan fungsional yang diperlukan untuk replikasi dan translasi virus. ${ }^{19}$ Sebelum menjadi 10 protein virus yang matang, poliprotein yang ditranslasikan dari ORF terlebih dahulu harus mengalami pemrosesan co-translasi dan post-translasi oleh enzim protease sel dan virus. ${ }^{10}$

Bagian N-terminal dari genom mengodekan protein struktural (C), prM dan $\mathrm{E}$ yang diikuti oleh protein nonstruktural NS1, NS2A, NS2B, NS3, NS4A, NS4B dan NS5. ${ }^{10}$ Ujung $\mathrm{N}$ dari gen prM, E, NS1 dan NS4B dipotong oleh signal peptidase sel inang yang terdapat dalam lumen retikulum endoplasma (RE). Pemrosesan sebagian besar protein nonstruktural yang lain dan ujung $C$ dari protein $\mathrm{C}$ terjadi di dalam sitoplasma sel 
inang yang dibantu oleh protease virus NS2B-3. Sekuens pada ujung C dari protein NS1 dipotong oleh protease yang terdapat di dalam RE, sementara pemotongan prM yang terjadi saat pematangan virion dimediasi oleh protease furin yang terdapat dalam badan Golgi. ${ }^{10}$

Terdapat 3 elemen utama yang diperlukan dalam replikasi DENV, yaitu: cis-acting element, trans-acting factor, dan viral-induced membrane. Cis-acting element terletak di dalam atau sekitaran 5'UTR- dan 3'-UTR-, trans-acting factor terletak di daerah origin sel dan viralinduced membrane membungkus kompleks replikasi (RC) dan kompartmen yang diperlukan dalam morfogenesis virus. ${ }^{10}$

\section{Cis-acting element}

Cis-acting element berfungsi sebagai promoter dalam replikasi RNA DENV. Sekuens regulator untuk genom DENV terutama dibentuk oleh sekuens berbentuk stem-loop dan linear yang terletak pada kedua ujung molekul RNA. Ada 6 elemen pada 5'-UTR genom DENV yang telah berhasil diidentifikasi, yaitu: stem-loop A (SLA), stem-loop B (SLB), daerah AUG 5'-upstream (5'-UAR), daerah AUG 5'downstream (5'-DAR), 5'-cyclization sequence (5'-CS), dan C-coding region hairpin (cHP). Tiga elemen terakhir terletak di dalam gen yang mengodekan protein C. $^{10}$

SLA terletak di ujung 5' pada genom RNA (Gambar 4). SLA sangat dibutuhkan untuk replikasi virus. Struktur SLA dibagi menjadi 6 daerah: Stem 1 (S1), UU bulge, stem 2 (S2), side-stem loop, stem 3 (S3) dan top loop. Analisis mutagenesis dari struktur SLA menunjukkan bahwa perpasangan basa pada bagian bawah SLA (S1 dan S2) yang diperlukan untuk replikasi virus tidak ada hubungannya dengan sekuens nukleotida yang ada. ${ }^{10}$ Penelitian menunjukkan bahwa SLA yang terlibat dalam replikasi RNA tidak berperan dalam translasi DENV. ${ }^{20}$

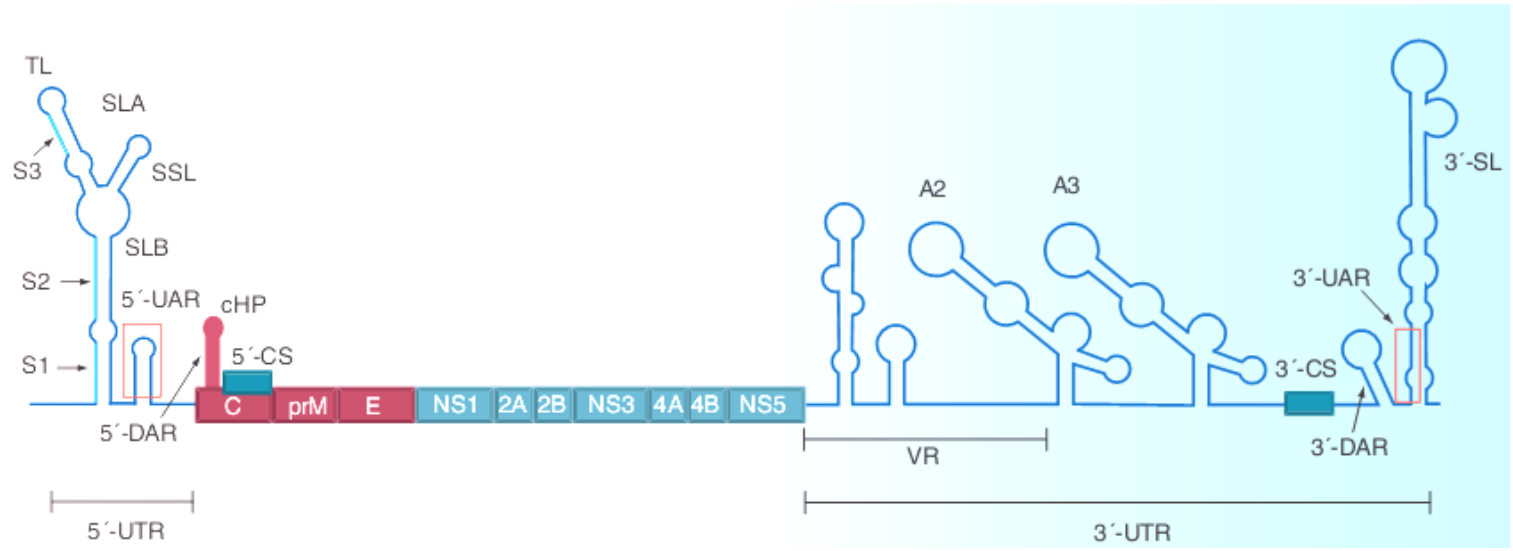

Gambar 4. Genom RNA virus dengue: Penekanan pentingnya peran Cis-acting element dalam proses replikasi virus. C: Kapsid; CS: Cyclization sequence; DAR: Downstream AUG region; E: Amplop; prM: Membran prekursor; S: Stem; SL: Stem loop; SLA: Stem-loop A; SLB: Stem-loop B; SSL: Side-stem loop; TL: Top loop; UAR: Upstream AUG region; UTR: Untranslated region; VR: Variable region. Sumber: Alcaraz-Estrada SL et al., 2010. ${ }^{10}$

\section{Trans-acting factor}

Selain cis-acting element, regulasi replikasi RNA DENV juga bergantung pada adanya trans-acting factor. Peran trans-acting factor harus terkoordinasi dengan cis-acting element agar dapat memroduksi jumlah RNA virus dalam jumlah yang memadai pada situs yang tepat. Terdapat dua jenis trans-acting factor yang terlibat dalam replikasi virus, yaitu: viral trans-acting factor dan cellular trans-acting factor. ${ }^{10}$ 
Viral trans-acting factor merupakan faktor yang terdapat di dalam virus itu sendiri. Viral trans-acting factor berupa protein NS1, NS2A, NS3, NS4A, NS4B dan NS5. Protein NS1 dan NS4A berperan sebagai komponen struktural pada kompleks replikasi yang melekatkan kompleks replikasi pada membran yang terinduksi virus. Interaksi protein NS4B dengan NS3 menyebabkan disosiasi NS3 dari ssRNA dan memicu pembukaan dsRNA. Protein NS3 yang merupakan viral protease (NS3pro), apabila berasosiasi dengan NS2B akan membentuk kompleks heterodimerik. Selain itu, NS3 juga mempunyai, aktivitas RNA trifosfatase dan RNA helikase. Protein NS5 berfungsi untuk menambahkan tudung pada RNA DENV karena memiliki aktivitas metiltransferase dan guanililtransferase. ${ }^{10}$

Cellular trans-acting factor yang merupakan komponen penting dari RC adalah elongation factor $1 a$ (EF1a), polypyrimidine tract binding protein (PTB), La, T-cell intracellular antigen-1 (TIA-1), protein yang berhubungan (TIAR), Y Box binding protein-1 (YB-1), calreticulin, PDI dan hnRNP A1, A2/B1 dan Q. ${ }^{10}$

\section{Kompleks replikasi (RC)}

Kompleks bermembran yang dibutuhkan untuk membentuk kompleks replikasi DENV adalah $\mathrm{RE}$ dan badan Golgi. Oleh karena itu sintesis RNA DENV berkaitan erat dengan membran intraseluler sel inang yang akan membentuk vesikelvesikel. Pembentukan membran interseluler menjadi vesikel tempat terjadinya sintesis RNA disebut kompleks replikasi. ${ }^{17}$ RC terbentuk saat pemrosesan protein selama translasi berlangsung dan pasca translasi (Gambar 5). ${ }^{10}$

Saat infeksi terjadi, genom virus terasosiasi dengan membran dari ER. RNA virus ditranslasikan oleh ribosom dalam protein struktural dan dibantu oleh protein nonstruktural virus. Replikasi RNA terjadi di dalam daerah RE yang mengalami invaginasi. Invaginasi RE diinduksi oleh protein nonstruktural, seperti NS3 dan NS4A. Setelah itu RNA diekspor ke convoluted membrane (CM). Langkah pertama dalam morfogenesis virus adalah perakitan RNA virus bersama protein kapsid. Setelah itu terbentuk budding virus pada RE yang kemudian membentuk vesikel yang dikirim ke Badan Golgi untuk pematangan virus. ${ }^{10}$

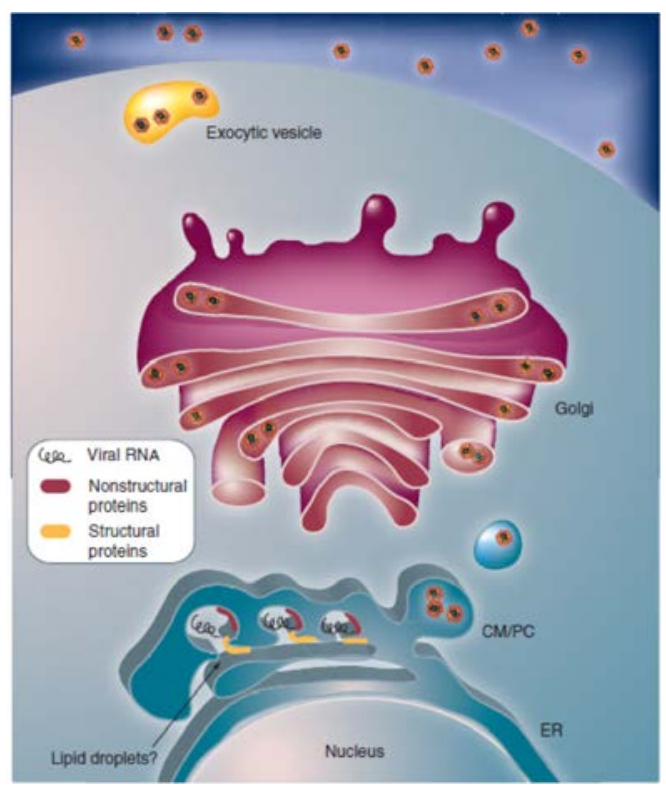

Gambar 5. Penggandengan antara translasi, replikasi dan morfogenesis DENV dalam membran terinduksi virus. CM: Convoluted membrane; ER: Retikulum endoplasma; PC: Paracrystalline arrays. Sumber: AlcarazEstrada SL et al., 2010. ${ }^{10}$

\section{SIMPULAN}

Genom Virus Dengue berukuran 11 kb yang tersusun atas 5'-untranslated region (5'-UTR), tiga gen struktural (mengodekan protein kapsid, premembran/membran dan amplop), tujuh gen non-struktural (mengodekan protein NS1, NS2A, NS2B, NS3, NS4A, NS4B dan NS5) dan 3'-UTR. Gen-gen non-struktural mengodekan protein untuk replikasi RNA virus, respon interferon, perakitan, sekresi partikel virus, menginduksi invaginasi membran retikulum endoplasma, induksi imunomediator dan penambahan tudung pada ujung 5' RNA. 


\section{DAFTAR PUSTAKA}

1. Centers for Disease Control (CDC). 2014. Epidemiology of dengue fever. [cited 2014 Sep 26]. Available from: http://www.cdc.gov/dengue/epidemiolog y/index.html

2. Cardozo DM, Moliterno RA, Sell AM, Guelsing SGA, Beltrame LM, Clemention SL, et al. Evidence of HLA-DQB1 contribution to susceptibility of dengue serotype 3 in dengue patients in Southern Brazil. Journal of Tropical Medicine. 2014:2. DOI: 10.1155/2014/968262.

3. Gubler DJ. The global emergence/resurgence of arboviral diseases as public health problems. Archives of Medical Research. 2002; 33(4):330-42. DOI: 10.1016/S0188-4409(02)00378-8.

4. Leardkamolkarn V, Sirigulpanit W, Kinney RM. Characterization of recombinant Dengue-2 virus derived from a single nucleotide substitution in the 5' noncoding region. $\mathrm{J}$ Biomed Biotechnol. 2010:1. DOI: 10.1155/2010/934694.

5. Fatima Z, Idrees M, Bajwa MA, Tahir Z, Ullah O, Zia MQ, et al. Serotype and Genotype analysis of dengue virus by sequencing followed by phylogenetic analysis using samples from three mini outbreaks-2007-2009 in Pakistan. BMC Microbiology. 2011;11(200):2-8. DOI: 10.1186/1471-2180-11-200.

6. Behura SK, Severson DW. Nucleotide substitutions in dengue virus serotypes from Asian and American countries: Insights into intracodon recombination and purifying selection. BMC Microbiology. 2013;13(37):1-11. DOI: 10.1186/1471-2180-13-37.

7. Guzman MG, Halstead SB, Artsob H, Buchy P, Farrar J, Gubler DJ, et al. Dengue: A continuing global threat. Nature Reviews Microbiology. 2010;8:S7-S16.

DOI: 10.1038/nrmicro2460.

8. Sellahewa KH. Pathogenesis of dengue haemorrhagic fever and its impact on case management. ISRN Infectious Diseases. 2013:1-6. DOI: 10.5402/2013/571646.

9. Seema, Jain SK. Molecular mechanism of pathogenesis of dengue virus: Entry and fusion with target cell. Indian Journal of
Clinical Biochemistry. 2005;20(2):92103. DOI: $10.1007 / B F 02867407$.

10. Alcaraz-Estrada SL, Yocupicio-Monroy M, del Angel MR. Insights into dengue virus genome replication. Future Virol. 2010;5(5):575-92. DOI: 10.2217/fvl.10.49.

11. Sankar SG, Dhanajeyan KJ, Paramasivan R, Thenmozhi V, Tyagi BK, Vennison SJ. High-level expression of functionally active Dengue-2 nonstructural antigen 1 production in Escherichia coli. BioMed Research International. 2013:1-6. DOI: 10.1155/2013/343195.

12. Dalrymple NA, Mackow ER. Roles for endothelial cells in dengue virus infection. Advances in Virology. 2012:1-8. DOI: 10.1155/2012/840654.

13. Rodriguez-Roche R, Gould EA. Understanding the dengue viruses and progress towards their control. BioMed Research International. 2013:1-20. DOI: 10.1155/2013/690835.

14. Chandramouli S, Joseph JS, Daudenarde S, Gatchalian J, Cornillez-Ty C, Kuhn P. Serotype-specific structural differences in the protease-cofactor complexes of the dengue virus family. Journal of Virology. 2010;84(6):305967. DOI: 10.1128/JVI.02044-09.

15. Amin N, Pupo M, Aguilar A, Camacho F, Alvarez M, Caballero $Y$, et al. Immunogenicity of NS4b Dengue 3 virus mimotope presented to the immune system as multiple antigen peptide system. ISRN Virology. 2013:1-7. DOI: 10.5402/2013/924057.

16. Hannemann H, Po-Yu S, Han-Cen C, Yousuf A, Bird J, Siew Pheng L, et al. Serotype specific differences in dengue virus non-structural protein 5 nuclear localization.

JBC. 2013;M113(481382):1-27. DOI: 10.1074/jbc.M113.481382.

17. Gebhard G, Filomatori CV, Gamarnik AV. Functional RNA elements in the dengue virus genome. Viruses. 2011;3:1739-56. DOI: 10.3390/v3091739.

18. Khan E, Hasan R, Mehraj J, Mahmood S. Genetic diversity of dengue virus and associated clinical severity during periodic epidemics in South East Asia, current topics in tropical medicine. 
78 Jurnal Biomedik (JBM), Volume 7, Nomor 2, Juli 2015, hlm. 71-78

InTech. Croatia, 2012. DOI: $10.5772 / 26115$.

2008;374:170-85.

DOI:

19. Yu L, Nomaguchi M, Padmanabhan R, Markoff L. Specific requirements for elements of the $5^{\prime}$ and $3^{\prime}$ terminal regions in Flavivirus RNA synthesis and viral

replication.

Virology. 10.1016/j.virol.2007.12.035.

20. Lodeiro MF, Filomatori C, Gamarnik AV. Structural and functional studies of the promoter element for dengue virus RNA replication. J. Virol. 2009;83:931008. DOI: 10.1128/JVI.01647-08. 